\title{
Continental copepod biodiversity in North-Eastern Borneo, Malaysia
}

\section{Биологическое разнообразие континентальных копепод Северного Борнео, Малайзия}

\author{
Victor R. Alekseev ${ }^{1,3^{*}}$, Fatimah M. Yusoff ${ }^{2}$, Elena B. Fefilova ${ }^{3,2}$ \\ Виктор Р. Алексеев ${ }^{1,3 *}$, Фатима М. Юсоф ${ }^{2}$, Елена Б. Фефилова ${ }^{3,2}$
}

\author{
${ }^{1}$ Zoological Institute, Russian Academy of Sciences, Universitetskaya Emb. 1, St. Petersburg, 199034 Russia. \\ ${ }^{2}$ Laboratory of Marine Biotechnology, Institute of Bioscience, Universiti Putra Malaysia, 43400 UPM-Serdang, Selangor, Malaysia. \\ ${ }^{3}$ Institute of Biology, Komi Scientific Centre, Ural Branch, Russian Academy of Sciences, Syktyvkar, Russia. \\ * Corresponding author: V.R. Alekseev (e-mail: alekseev@zin.ru or valekseev2@yahoo.com)
}

KEY WORDS: zooplankton, copepod faunà survey. tropic ecosystems, de-forestation anthropogenic effects.

КЛЮЧЕВЫЕ СЛОВА: зоопланктон, фауна веслоногих раков, тропические пресноводные экосистемы, вырубка лесов, антропогенные эффекты.

\begin{abstract}
To obtain a relevant information on copepod biodiversity/distribution in continental Borneo water bodies in June 2011 about 30 different sites in Malaysian state Sabah were visited and more than 50 alcohol and formalin preserved samples in nine rivers, 10 ponds, and six near-road ditches and canals, rice fields and forest leaf litter environment were collected. In literature 16 copepod species were referred for Borneo and 10 other species for Kalimantan (Indonesean) states. After the Sabah sample analyses, the copepodspecies richnessin the Borneo island increased more than twice. The most abundant with species number genera were ranged as: Mesocyclops (13), Elaphoidella (6), Microcyclops (5), Eucyclops (4), Thermocyclops (4), Halicyclops (3) and Paracyclops (3). Species biodiversity in different sites plotted against type of water body and several environment parameters revealed significant positive correlations for number of species and both for depth and temperature in sampling site (Pearson non-parametric tests 0.6 and 0.5 respectively at $p<0.05$ ). One way Kruscal-Walise dispersal analysis confirmed significant relationship between copepod biodiversity and water transparence/ turbidity $(\mathrm{p}<0.05)$. The highest copepod biodiversity values were found in ponds ( 23 species), near road ditches (15), rivers with transparent water (12), lowland or swamp areas related with rivers (9). The lowest number of species were found in rivers with turbid water colored in orange with soil-erosive matter where the average number of copepod species $(0.2 \pm 0.08$ species per site) was about 20 times less than in waters without silt particles ( $3.8 \pm 2.8$ species per site). This indicates a strong negative effect of soil erosion resulting water land-used activities and deforestation in the watershed on the biodiversity of aquatic organisms in Borneo. In one sub-urban population of Mesocyclops cf. thermocyclopoides, a trans-sexual mutation of female-sized but constructed as male armed with genicu-
\end{abstract}

late antennule organisms was found that possibly reflect a negative result of wide artificial hormone-based pesticide usage in this area. Keys for Harpacticoida species for Borneo and for Eucyclops species known for SEAsia, Australia and India are provided. Within practically each copepod genus studied in Borneo there are forms with problems on species identification by existing faunistic keys. This possibly indicates a necessity of new species description from this area in the nearest future.

РЕЗЮМЕ. Для получения актуальной информации по биоразнообразию и распространению веслоногих раков в континентальных водоемах Борнео в июне 2011 г. в Малазийском штате Сабах были исследованы около 30 разных биотопов, в которых отобрали более 50 спиртовых и формалиновых проб зоопланктона. Параллельно в девяти реках, 10 прудах, шести придорожных канавах и оросительных каналах, рисовых полях и пересыхающих временных водоемах в широко-лиственных лесах регистрировали важнейшие параметры среды обитания. До нашего исследования из литературы для Северного Борнео были известны 16 видов веслоногих раков и 10 видов копепод указаны для индонезийской части острова. После анализа образцов из одного только штата Сабах известное для Борнео число видов копепод увеличилось более чем в два раза. Наибольшее их число установлено для родов Mesocyclops (13), Elaphoidella (6), Microcyclops (5), Eucyclops(4), Thermocyclops (4), Halicyclops (3) и Paracyclops (3). Видовое разнообразие зависело от типа водоема и нескольких параметров окружающей среды, что было подтверждено значимыми положительными корреляциями для числа видов и глубины, а также температуры (непараметрические критерии Пирсона 0,6 и 0,5 соответственно при $\mathrm{p}<0,05)$. Анализ Краскела-Уоллеса под- 
твердил значимую связь между разнообразием копепод и прозрачностью воды воды/мутностью (p < $0,05)$. Высокие показатели разнообразия копепод были обнаружены в прудах (23 вида), придорожных канавах (15), реках с прозрачной водой (12), заболоченных низинах, связанных с реками (9). Наименьшее число видов обнаружено в реках с мутной водой, окрашенных в оранжевый цвет почвенноэрозионной взвесью $(0,2 \pm 0,08$ видов на биотоп). Оно было примерно в 20 раз меньше, чем в водоемах без илистых частиц $(3,8 \pm 2,8$ видов на биотоп). Это указывает на сильное негативное влияние эрозии почв и вырубки лесов в бассейнах рек на биоразнообразие водных организмов на Борнео. В одном из пригородов столицы штата у массового вида копепод Mesocyclops thermocyclopoides, было обнаружено явление транс-сексуальной мутации особей женского пола, построенных как самцы в строении антеннул (преобразованы в геникулирующие), что, возможно, отражает отрицательный результат использования пестицидов на основе искусственных гормонов. Приведены ключи для видов отряда Harpactiformes Борнео и рода Eucyclops из Юго-Восточной Азии, Австралии и Индии. Наличие практически в каждом роде копепод трудно определяемых или не определяемых по существующим ключам видов указывает на возможность описания с Борнео новых таксономических единиц в самой ближайшей перспективе.

\section{Introduction}

The island Borneo consisting of Malaysia (Sarawak and Sabah), Brunei and Indonesia (= Kalimantan) is the third largest island on the planet with the oldest tropical forest ecosystem, at the same time remains as the one of largest white spots for aquatic invertebrate biodiversity. The WWF [WWF-Cannon, 2010] stated that 413 vertebrate animal and plant species have been discovered in Borneo since 1996. Aquatic vertebrate biodiversity in Borneo is also very rich and includes 160 (19 endemic) fish species, 100 amphibian species, most of which are endemic to the territory. In contrast to vertebrates, aquatic invertebrates of Borneo are poorly studied and till our expedition, included 26 species of entomostracan crustaceans, 1 species of nematode, 25 species of decapods, 16 species of polychaetes, 10 species of oligochaetes, 51 species of aquatic insects and one species of echinoderm. As the preliminary result of our study, the number of aquatic nematode species in Borneo has increased up to 15 species [Tsalolikhin et al., 2012]. Altogether this comprises a very short list for aquatic invertebrate biodiversity of a tropical ecosystems with exception of insect counts of about 90 species. For comparison, in Amazonian tropical forest ecosystem, there are more than 250 species only among freshwater gastropods [Simone, 2006]. To some extent, this paucity of aquatic invertebrate biodiversity in Borneo can be due to rare visits by naturalists and scientific expeditions in 19-20 centuries and/or their particular interest to large size animals like freshwater crabs or shrimps. The first data on freshwater invertebrate fauna of Borneo were obtained in the end of 19th century during the Dutch Scientific Expedition to central Borneo, when several new species of freshwater Palemon (Macrobrachium) were described [De Man, 1898]

Of three cyclopoid species found by Spandl [1924], Cyclops strenuus Fischer, 1851, Cyclops (Megacyclops) viridis (Jurine, 1820), Cyclops (Macrocyclops) fuscus (Jurine, 1820), the validity of identification of the first species inhabiting mainly high latitudes in Palearctic was under doubt since it was published [Lindberg, 1954] and the same critic will be applied to two others hereafter. A very short visit of Humes in 1945 to Borneo allowed him to specify Halicyclops caridophilus $\mathrm{Hu}-$ mes, 1947, which was still not found after him. Lindberg [1954] from the same samples collected by $\mathrm{Hu}-$ mes in Borneo described Apocyclops borneoensis Linberg, 1954, later found in many other SEAsian countries and in Japan [Ishida, 2002; Dussart, Defaye, 2003].

Brehm [1953] and Kiefer [1965] later on explored some Woltersk's samples of the Wallacea expedition and found or described two more freshwater copepod species from this area, including endemic-like diaptomid Philodiaptomus longipes Kiefer, 1965, which was never found after the description.

Several species of Mesocyclops were found or described from Norhtern Borneo/Kalimantan by B. Dussart [Dussart, 1985; Dussart, Fernado, 1986; Dussart, Sarnita, 1987]. The biggest contribution to copepod biodiversity of Norhtern Borneo was done by Löffler [1973] who collected and identified five Harpacticoida species from the island. Three of them, Maraenobiotus kinabaluensis, Löffler, 1973, Elaphoidella labani Löffler, 1973, Attheyella (Canthosella) silvicola Löffler, 1973 became new for sciences and were described from Sabah, in small water bodies in vicinity the highest of SEAsia mountain, Mt. Kinabalu. Similar large impact to copepod fauna of Kalimantan states was provided by Maria Holynska [2000] who found five species of Mesocyclops with M. dayakorum Holynska, 2000 as new for sciences.

In total, 26 copepod species (13 Cyclopoida, 8 Harpacticoida and 5 Calanoida) were found in Borneo/ Kalimantan before our study, that should be only evaluated as a preliminary data on biodiversity in this group for such a large tropical island. Such clear contrast between known and promising species richness in aquatic organism from Borneo became a factor stimulating our study. Also important point to do such a survey became a warry on fast declining in continental aquatic fauna biodiversity in Boneo caused by intensive exploration of natural resourses in the island.Thus, the main goals of our study became 1 to contribute more information on biodiversity and distribution of continental copepod in Borneo, 2 to study correlation copepod species richness with several major environmental factors (temperature, $\mathrm{pH}$, water conductivity etc) 3.to elu- 


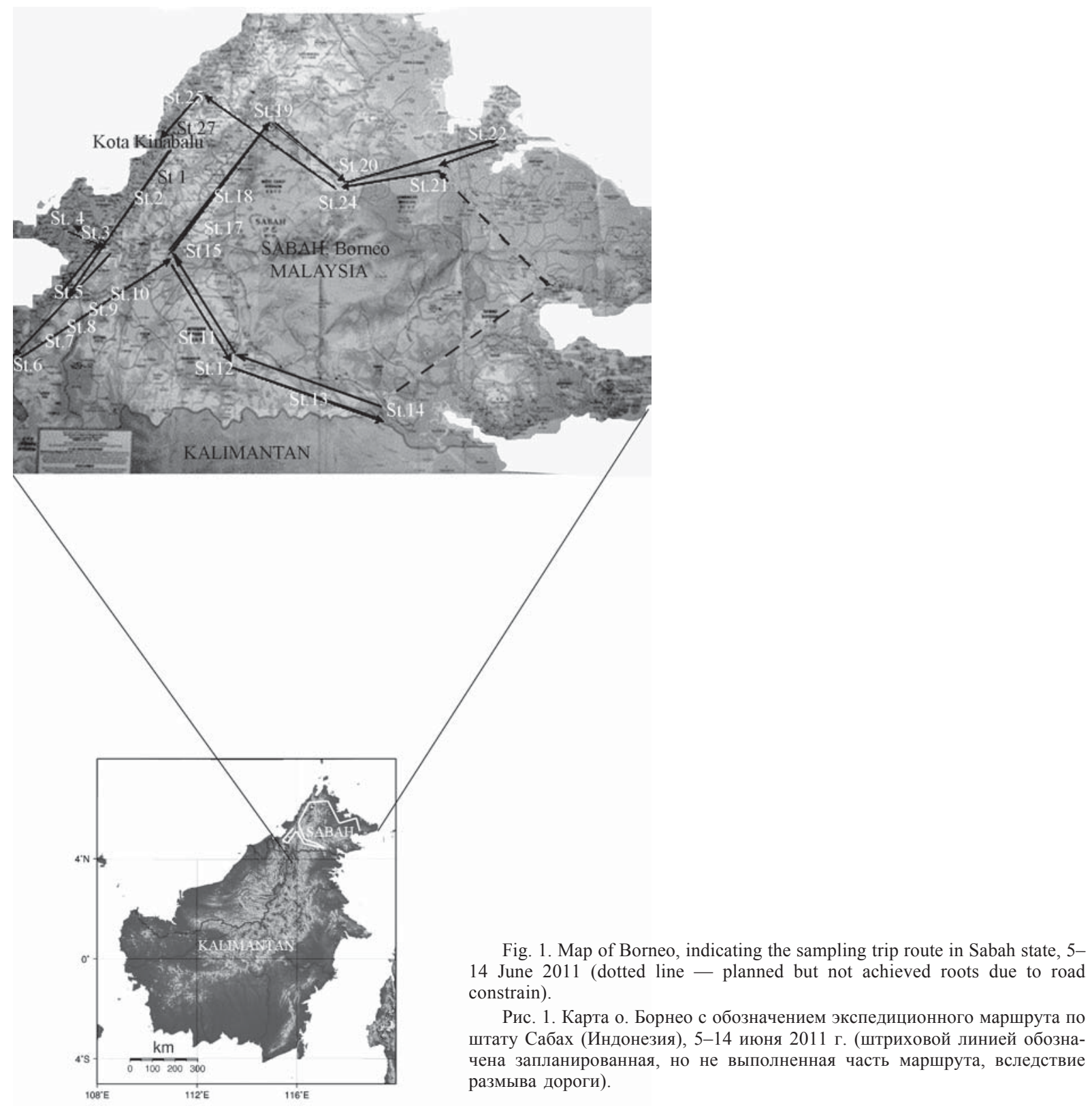

cidate possible impacts of human activities such as deforestation and following soil erosion on the aquatic fauna.

Samples of littoral and open water zooplankton were collected in a field trip to Sabah state of Borneo on 8-15 June 2011. A round-way trip along coastal area and close to coast roots started from the state capital Kota Kinabalu on 9 June morning and completed in the same city on 14 June afternoon (Fig. 1). More than 30 sampling stations were visited within 5 days (Table 1). Littoral zooplankton was collected with a hand net of triangular shape and mesh size about 100 $\mathrm{mcm}$, and for open water organism, we used horizontal towing with of plankton net, open mouth diameter 25 $\mathrm{cm}$, mesh size $60 \mathrm{mcm}$. For every station, with a few exceptions, geographical coordinates were recorded with Garmin GPS. In parallel with zooplankton sampling, some basic environmental parameters were determined using a water quality multiprobe (Hydrolab Surveyor Data Sonde 4) that included depth, temperature, $\mathrm{pH}$, conductivity and dissolved oxygen whenever possible. Additional information on sampling sites were obtained after visual observations and include type of water body, water colour, current speed, smell, presence/absence of aquatic plants, fish, reptilians, aquatic birds, names of nearest town or river, specific characters of biotopes (Table 1). In five days, about 100 alcohol and formalin preserved samples from 16 rivers, 10 ponds, and six special biotopes (near-road ditches, concrete rain-water collectors, rice fields, forest 
Table 1. A brief description of the sampling stations, Sabah, Malaysia, 9-14 June 2011. Таблица 1. Краткое описание мест сбора проб, штат Сабах, Малайзия, 9-14 июня 2011 г.

\begin{tabular}{|c|c|c|c|c|}
\hline Dates & $\begin{array}{l}\text { Station } \\
\text { NN }\end{array}$ & Coordinates & Type /name of water body, nearest town & $\begin{array}{l}\text { Environmental conditions: } \\
\text { Temperature, depth, } \mathrm{pH}, \\
\text { conductivity, dissolved oxygen }\end{array}$ \\
\hline \multirow{5}{*}{9.06} & 1 & $\begin{array}{l}5^{\circ} 49.930^{\prime} \mathrm{N} \\
116^{\circ} 02.365^{\prime} \mathrm{E}\end{array}$ & Near road ditch, Kinarut town & $\begin{array}{l}29 \text { to } 31^{\circ} \mathrm{C} \text { (at the surface); depth } \\
25 \mathrm{~cm} ; \mathrm{pH} 6.0\end{array}$ \\
\hline & 2 & $\begin{array}{l}5^{\circ} 46.222^{\prime} \mathrm{N} \\
115^{\circ} 58.016^{\prime} \mathrm{E}\end{array}$ & $\begin{array}{l}\text { Near roadside rain pool, near swamp. } \\
\text { Pengalat town }\end{array}$ & $31^{\circ} \mathrm{C}$; depth $50 \mathrm{~cm}$; pH 5 \\
\hline & $2 b$ & $\begin{array}{l}5^{\circ} 6.222^{\prime} \mathrm{N} \\
115^{\circ} 58.016^{\prime} \mathrm{E}\end{array}$ & The same place near aquatic plants & $30^{\circ} \mathrm{C}$; depth $15 \mathrm{~cm}$ \\
\hline & $2 \mathrm{a}$ & $\begin{array}{l}5^{\circ} 43^{\prime} \mathrm{N} \\
115^{\circ} 56^{\prime} \mathrm{E}\end{array}$ & Papar river, shallow river bank & $\begin{array}{l}30^{\circ} \mathrm{C} \text {; depth } 115 \mathrm{~cm} ; \mathrm{pH} 7.6 \\
\text { dissolved } \mathrm{O}_{2} 6.78 \mathrm{mg} \mathrm{L}^{-1} \\
\text { conductivity } 35 \mu \mathrm{S} \mathrm{cm}^{-1}\end{array}$ \\
\hline & 3 & $\begin{array}{l}5^{\circ} 21.779^{\prime} \mathrm{N} \\
115^{\circ} 34.441^{\prime} \mathrm{E}\end{array}$ & $\begin{array}{l}\text { Canal near Garama River (Garama } \\
\text { floodplain) }\end{array}$ & $27^{\circ} \mathrm{C}$; depth $50 \mathrm{~cm} ; \mathrm{pH} 6.0$ \\
\hline \multirow{5}{*}{10.06} & $4,4 \mathrm{a}-\mathrm{f}$ & $\begin{array}{l}5^{\circ} 21.779^{\prime} \mathrm{N} \\
115^{\circ} 34.441^{\prime} \mathrm{E}\end{array}$ & $\begin{array}{l}\text { Low land near Garama River with flooded } \\
\text { water (floodplain) }\end{array}$ & $27^{\circ} \mathrm{C}$; depth $30 \mathrm{~cm} ; \mathrm{pH} 6.0$ \\
\hline & $5,5 \mathrm{a}-\mathrm{b}$ & $\begin{array}{l}5^{\circ} 21.015^{\prime} \mathrm{N} \\
115^{\circ} 35.762^{\prime} \mathrm{E}\end{array}$ & A fish pond in a village orchard, in Garama & $30^{\circ} \mathrm{C}$, depth $25 \mathrm{~cm} ; \mathrm{pH} 7.15$ \\
\hline & $6,6 a$ & $\begin{array}{l}4^{\circ} 57.945^{\prime} \mathrm{N} \\
115^{\circ} 29.065^{\prime} \mathrm{E}\end{array}$ & $\begin{array}{l}\text { Rain water collector, Sindumin (border } \\
\text { town between Sabah and Sarawak) }\end{array}$ & $\begin{array}{l}30^{\circ} \mathrm{C} \text {, depth } 15 \mathrm{~cm} ; \mathrm{pH} 6.3 \\
\text { dissolved oxygen } 4.0 \mathrm{mg} \mathrm{L}^{-1}\end{array}$ \\
\hline & 7 & $\begin{array}{l}4^{\circ} 58.500^{\prime} \mathrm{N} \\
115^{\circ} 31.324^{\prime} \mathrm{E}\end{array}$ & $\begin{array}{l}\text { Canal in near road small river, Skim village, } \\
\text { Sindumin }\end{array}$ & $\begin{array}{l}29.4^{\circ} \mathrm{C} ; \mathrm{pH} 3,69 ; \text { conductivity } \\
24 \mu \mathrm{S} \mathrm{cm}^{-1} ; \text { dissolved oxygen } \\
2.74 \mathrm{mg} \mathrm{L}^{-1}\end{array}$ \\
\hline & 8 & $\begin{array}{l}4^{\circ} 59.103^{\prime} \mathrm{N} \\
115^{\circ} 37.553^{\prime} \mathrm{E}\end{array}$ & $\begin{array}{l}\text { Malaman river, Melagau village, Tenom. } \\
\text { Interior Division of Sabah }\end{array}$ & $\begin{array}{l}27.5^{\circ} \mathrm{C} ; \mathrm{pH} 6.8 ; \text { conductivity } 38 \\
\mu \mathrm{S} \mathrm{cm}^{-1} \text {, dissolved oxygen } 5.2 \\
\mathrm{mg} \mathrm{L}^{-1}\end{array}$ \\
\hline \multirow{7}{*}{11.06} & 9 & & $\begin{array}{l}\text { Artificial concrete pond in Hillview Garden } \\
\text { Resort, Keningau }\end{array}$ & $31^{\circ} \mathrm{C}$, depth $30 \mathrm{~cm}$ \\
\hline & 10 & $\begin{array}{l}5^{\circ} 05.267^{\prime} \mathrm{N} \\
116^{\circ} 26.947^{\prime} \mathrm{E}\end{array}$ & $\begin{array}{l}\text { Near road pond from Sook to Nabawan. } \\
\text { Submerged macrophytes, very brown water }\end{array}$ & $\begin{array}{l}26.1^{\circ} \mathrm{C} ; \mathrm{pH} \text { 6.12; conductivity } \\
44 \mu \mathrm{S} \mathrm{c}^{-1} ; \text { dissolved oxygen } \\
2.01 \mathrm{mg} \mathrm{L}^{-1} \text {. }\end{array}$ \\
\hline & $11 \mathrm{a}$ & $\begin{array}{l}4^{\circ} 42.246^{\prime} \mathrm{N} \\
116^{\circ} 30.32^{\prime} \mathrm{E}\end{array}$ & $\begin{array}{l}\text { Aborigines village Murut tribe, in Sepuluk. } \\
\text { Pond in oil palm plantation, near a small } \\
\text { stream flowing into Sepuluk river }\end{array}$ & $26^{\circ} \mathrm{C}$; pH 6; depth $80 \mathrm{~cm}$ \\
\hline & $11 \mathrm{~b}$ & $\begin{array}{l}4^{\circ} 42.246^{\prime} \mathrm{N} \\
116^{\circ} 30.32^{\prime} \mathrm{E}\end{array}$ & $\begin{array}{l}\text { Sepuluk river. Sampled in the shallow } \\
\text { weedy river bank }\end{array}$ & $\begin{array}{l}26.1^{\circ} \mathrm{C} ; \mathrm{pH} 6.15 ; \text { conductivity } 41 \\
\mu \mathrm{S} \mathrm{cm}^{-1}\end{array}$ \\
\hline & $\begin{array}{l}12, \\
12 \mathrm{a}, \mathrm{b}\end{array}$ & $\begin{array}{l}4^{\circ} 39.911^{\prime} \mathrm{N} \\
116^{\circ} 33.255^{\prime} \mathrm{E}\end{array}$ & $\begin{array}{l}\text { Simatuoh river, located between Sepuluk } \\
\text { and Tambulanan villages }\end{array}$ & $\begin{array}{l}24.4^{\circ} \mathrm{C} ; \mathrm{pH} 7.24 ; \text { conductivity } 32 \\
\mu \mathrm{S} \mathrm{cm}^{-1}\end{array}$ \\
\hline & 13 & $\begin{array}{l}4^{\circ} 35.158^{\prime} \mathrm{N} \\
116^{\circ} 56.978^{\prime} \mathrm{E}\end{array}$ & Meliau river & $\begin{array}{l}24.6^{\circ} \mathrm{C} ; \mathrm{pH} 5.45 ; \text { conductivity } \\
41 \mu \mathrm{S} \mathrm{cm}^{-1} ; \text { dissolved oxygen } \\
7.35 \mathrm{mg} \mathrm{L}^{-1} \text {; rocky river }\end{array}$ \\
\hline & 14 & $\begin{array}{l}4^{\circ} 32.311^{\prime} \mathrm{N} \\
117^{\circ} 02.378^{\prime} \mathrm{E}\end{array}$ & River Kuamat Not very far to Station 13 & $\begin{array}{l}24.8^{\circ} \mathrm{C} ; \mathrm{pH} 5.9 ; \text { conductivity } 41 \\
\mu \mathrm{S} \mathrm{cm}^{-1}\end{array}$ \\
\hline \multirow{6}{*}{12.06} & 15 & $\begin{array}{l}5^{\circ} 38.520^{\prime} \mathrm{N} \\
116^{\circ} 21.513^{\prime} \mathrm{E}\end{array}$ & $\begin{array}{l}\text { Weedy ponds in a vegetable garden in } \\
\text { Apin-Apin village }\end{array}$ & $\begin{array}{l}26.2^{\circ} \mathrm{C} ; \mathrm{pH} 6.0 ; \text { depth } 30 \mathrm{~cm} ; \\
\text { conductivity } 52 \mu \mathrm{S} \mathrm{cm}^{-1}\end{array}$ \\
\hline & 16 & $\begin{array}{l}5^{\circ} 38.520^{\prime} \mathrm{N} \\
116^{\circ} 20.513^{\prime} \mathrm{E}\end{array}$ & Pond with lotus, Tambunan town & $\begin{array}{l}28^{\circ} \mathrm{C} \text {; depth } 15 \mathrm{~cm}, \mathrm{pH} 5,44 \\
26.2^{\circ} \mathrm{C} \text {; pH } 6.3 \text {; conductivity } 42 \\
\mu \mathrm{S} \mathrm{cm}^{-1}\end{array}$ \\
\hline & $17 \mathrm{a}-\mathrm{b}$ & $\begin{array}{l}5^{\circ} 42.811^{\prime} \mathrm{N} \\
116^{\circ} 24.096^{\prime} \mathrm{E}\end{array}$ & Rice field, Lumando village, Tambunan & $\begin{array}{l}31.5^{\circ} \mathrm{C} \text {; depth } 10 \mathrm{~cm} ; \mathrm{pH} 5.3 \\
\text { conductivity } 36 \mu \mathrm{S} \mathrm{cm}^{-1}\end{array}$ \\
\hline & 18 & $\begin{array}{l}5^{\circ} 47.271^{\prime} \mathrm{N} \\
116^{\circ} 28.287^{\prime} \mathrm{E}\end{array}$ & Brown water pond, Tiang village & $\begin{array}{l}25.7^{\circ} \mathrm{C} \text {; depth } 40 \mathrm{~cm} ; \mathrm{pH} 4.37 \\
\text { conductivity } 57 \mu \mathrm{S} \mathrm{cm}^{-1}\end{array}$ \\
\hline & 19 & $\begin{array}{l}5^{\circ} 56.769^{\prime} \mathrm{N} \\
116^{\circ} 46.67^{\prime} \mathrm{E}\end{array}$ & Maroli river, Luantiti village, Ranau & $\begin{array}{l}26.1^{\circ} \mathrm{C} ; \mathrm{pH} 6.85 ; \text { conductivity } 47 \\
\mu \mathrm{S} \mathrm{cm}\end{array}$ \\
\hline & $20 a-d$ & $\begin{array}{l}5^{\circ} 48.222^{\prime} \mathrm{N} \\
116^{\circ} 49.031^{\prime} \mathrm{E}\end{array}$ & $\begin{array}{l}\text { Upstream of Kinabatangan river with fast } \\
\text { stream; shallow with clear water }\end{array}$ & $\begin{array}{l}24.7^{\circ} \mathrm{C} \text {; depth } 50 \mathrm{~cm} \text {; pH } 6.73 \text {; } \\
\text { conductivity } 47 \mu \mathrm{sm}^{-1}\end{array}$ \\
\hline
\end{tabular}


Table 1 (continued). Таблица 1 (продолжение).

\begin{tabular}{|c|c|c|c|c|}
\hline Dates & $\begin{array}{l}\text { Station } \\
\text { NN }\end{array}$ & Coordinates & Type /name of water body, nearest town & $\begin{array}{l}\text { Environmental conditions: } \\
\text { Temperature, depth, } \mathrm{pH}, \\
\text { conductivity, dissolved oxygen }\end{array}$ \\
\hline \multirow{4}{*}{13.06} & $21,21 b$ & $\begin{array}{l}5^{\circ} 30.663^{\prime} \mathrm{N} \\
117^{\circ} 50.663^{\prime} \mathrm{E}\end{array}$ & $\begin{array}{l}\text { Sandakan town Brown water pond near the } \\
\text { roadside, located in a palm oil plantation. } \\
\text { Weedy with a lot of submerged } \\
\text { macrophytes }\end{array}$ & $\begin{array}{l}29.1^{\circ} \mathrm{C} ; \mathrm{pH} 6.27 \text {; conductivity } 50 \\
\mu \mathrm{S} \mathrm{cm}^{-1}\end{array}$ \\
\hline & $22 \mathrm{a}, \mathrm{b}$ & $\begin{array}{l}5^{\circ} 33.971^{\prime} \mathrm{N} \\
117^{\circ} 58.895^{\prime} \mathrm{E}\end{array}$ & $\begin{array}{l}\text { Genting-Sekong Oil Palm Estate ponds, } \\
\text { Gomantong village }\end{array}$ & $\begin{array}{l}31.4^{\circ} \mathrm{C} ; \mathrm{pH} 8.2, \text { conductivity } 62 \\
\mu \mathrm{S} \mathrm{cm}\end{array}$ \\
\hline & 23 & $\begin{array}{l}5^{\circ} 29.827^{\prime} \mathrm{N} \\
118^{\circ} 12.316^{\prime} \mathrm{E}\end{array}$ & $\begin{array}{l}\text { Kinabatangan river with low stream, Bilit } \\
\text { village }\end{array}$ & $\begin{array}{l}28.1^{\circ} \mathrm{C} \text {; depth } 200 \mathrm{~cm} ; \mathrm{pH} 6.61 \\
\text { conductivity } 40 \mu \mathrm{S} \mathrm{cm}^{-1}\end{array}$ \\
\hline & 24 & $\begin{array}{l}5^{\circ} 31.385^{\prime} \mathrm{N} \\
118^{\circ} 12.437^{\prime} \mathrm{E}\end{array}$ & $\begin{array}{l}\text { Wet leaf litter collected in Kinabatangan } \\
\text { virgin forest }\end{array}$ & No water on surface \\
\hline \multirow{3}{*}{14.06} & $25,25 b$ & $\begin{array}{l}5^{\circ} 56.556^{\prime} \mathrm{N} \\
116^{\circ} 02.788^{\prime} \mathrm{E}\end{array}$ & $\begin{array}{l}\text { Sand beach in Kota Kinabalu, interstitial } \\
\text { water }\end{array}$ & $\begin{array}{l}26.5^{\circ} \mathrm{C} \text {; depth } 40 \mathrm{~cm} ; \mathrm{pH} 4.39 \\
\text { conductivity } 51 \mu \mathrm{S} \mathrm{cm}^{-1}\end{array}$ \\
\hline & $26 \mathrm{a}-\mathrm{e}$ & $\begin{array}{l}5^{\circ} 59.657^{\prime} \mathrm{N} \\
116^{\circ} 06.287^{\prime} \mathrm{E}\end{array}$ & Pond in Kota Kinabalu with aquatic plants & $\begin{array}{l}27.2^{\circ} \mathrm{C} ; \mathrm{pH} 6.38 ; \text { conducitivity } \\
75 \mu \mathrm{S} \mathrm{cm}^{-1}\end{array}$ \\
\hline & 27 & $\begin{array}{l}5^{\circ} 59.556^{\prime} \mathrm{N} \\
116^{\circ} 06.128^{\prime} \mathrm{E}\end{array}$ & Open water in the same pond & $\begin{array}{l}28.2^{\circ} \mathrm{C} ; \mathrm{pH} 6.84 ; \text { conductivity } 73 \\
\mu \mathrm{S} \mathrm{cm}^{-1}\end{array}$ \\
\hline
\end{tabular}

leaf litter environment, interstitial water in sand beach) were collected.

Within one week after collection, the samples were sorted in the Laboratory of Marine Biotechnology, Institute of Bioscience, University Putra Malaysia, under binocular microscope with maximum resolution of 250x. All copepods were picked up and separated in glass tubes in accordance to their suborder. Following species identification after dissection, each specimen was placed separately in a glycerin drop covered with cover glass and fixed with Canadian balsam. The slides were then observed, photographed (with videocamera Levenhuk C8000) and if necessary drawn at maximum resolution up to $1000 \times(10 \times$ ocular, $100 \times$ objective, oil immersion) under a compound microscope (Zeiss IMAGER) equipped with Nomarski's system for differential interference contrast microscopy and a drawing tube (for cyclopoid and calanoid species). For the preparation of harpacticoid specimens and drowning, a microscope Leica DM 4000 B with a drawing tube was used. Initial pencil drawings were converted to black with fine marker Pilot 0.3 and $0.5 \mathrm{~mm}$ and then placed on A4 size tracing paper. Scanned tables of images at a resolution up to $600 \mathrm{dpi}$, were than numbered and reorganized with a computerized graphics program (Adobe Photoshop). Body measurements were mainly done on undissected, or carefully dissected and gently fixed in ventral position without compression animals with a cover slide provided with plasticine tombs.

For data analyses, STATISTICA 6.1 program package was used. To avoid low normality distribution of the field data we used the non-parametric Spearman test for correlation of number of copepod species and environmental data in the sampling sites. Kruskal-Wallis ANOVA was applied for dispersal analyses for types of water body (river with turbid water versa river with transparent water; river versa pond etc) as independent variables and species number, depth, temperature, $\mathrm{pH}$, conductivity and dissolved oxygen as dependent variables.

For external copepod morphology, we mainly followed terminology of Huys and Boxshall [1991].

\section{Results}

\section{Environmental parameter variation}

\section{Temperature}

During our trip surface water temperature were measured in situ during the day or night. The mean value was $27.9 \pm 1.36^{\circ} \mathrm{C}$ with relatively low fluctuation $(24.0$ $31.5^{\circ} \mathrm{C}$ ), reflecting stable temperature conditions in the equatorial zone. Pearson test revealed an average (0.57) significant at level $\mathrm{p}<0.05$, positive correlation of temperature and species number both for all types of water bodies and separately for ponds, special biotopes and rivers.

\section{pH}

This parameter in tropical forest area usually indicates acid conditions, and in our case the average $\mathrm{pH}$ value was quite low $5.96 \pm 0.82$ but min-max variation was high $3.7-8,2$. The minimal $\mathrm{pH}$ was found in a shallow rain-draining canal at a road side (St. 7), and the maximal one in a small artificial concrete pond with dark green water full of aquatic plants (St. 22). In both cases we found alive copepods in high density and a number of different species (3-4 species for site). No significant correlation $(p<0.05)$ was detected between the number of copepod species and $\mathrm{pH}$ indicating that local species are well adopted to live in quite wide 
range of this parameter. A significant positive correlation $(\mathrm{r}=0.6, \mathrm{p}<0.05)$ were found for $\mathrm{pH}$ and depth.

\section{Dissolved oxygen}

This parameter was estimated in a limited number of sites (six locations) and fluctuated from $2.0 \mathrm{ml} \mathrm{L}^{-1}$ (St. 10) to $7.35 \mathrm{mg} \mathrm{L}^{-1}$ (St. 13) with a mean value of $4.72 \pm 0.97 \mathrm{mglL}^{-1}$. At the site with maximal dissolved oxygen value ( Meliau stream), we did not find any copepods, whereas at the site with minimal oxygen concentration (near road pond), two copepod species were found. No regularity in relationship can be seen between the number of copepod species and dissolved oxygen, probably due to the masking effects of fast currents in the mountain stream (Meliau) that was not conducive for copepods.

\section{Conductivity}

Conductivity, with an average value of $45.0 \pm 9.27$ $\mu \mathrm{S} \mathrm{cm}^{-1}$, also did not show significant fluctuations (24.0-75.0 $\mu \mathrm{S} \mathrm{cm}^{-1}$ ) amongst the sampling sites..The maximal value was observed in a near shore pond (St. 26, 27) probably due to influence of the nearby sea water. Conductivity did not show any significant correlation with copepod biodiversity $(p>0.05)$ in all types of waterbodies. The number of species at the site with the lowest conductivity value (St. 7 with 3 species) did not differ with that observed at the station with the highest conductivity value (St. 26, four species)

\section{Depth}

Minimal depth in sampling sites (st. 17a, a rice field) was $10 \mathrm{~cm}$ and maximal depth $(200 \mathrm{~cm})$ was in the River Kinabatangan (st. 23). We found significant positive correlations for copepod species diversity $(\mathrm{r}=$ $0.57 ; \mathrm{p}<0.05$ ) and the depth in the sampling place both for all types of waterbodies and separately for rivers and, ponds. Deeper water bodies seemed to be more stable and tend to accommodate higher number of species than the temporay biotopes.

\section{Copepod biodiversity in Borneo}

In samples collected during our trip in Sabah, we found 41 copepod species, that increased biodiversity of these crustaceans in Borneo more than four times. The total number of species for the wholel island now includes 57 species with 8 species (Diaptomids mainly) known only for Kalimantan and 49 species comprised in 20 genera for Borneo. Before our study only 24 copepod species were known for both Malaysian states in Borneo (Table 2).

The most abundant number of species according to genera are: Mesocyclops (13 species), Elaphoidella (6), Microcyclops (5), Eucyclops (4), Thermocyclops (4), Halicyclops (3) and Paracyclops (3) (Table 2). The highest copepod biodiversity was found in ponds (23), near road ditches (15), rivers with transparent water (12), low-land or swamp areas related with rivers (9). The lowest number of species were found in rivers with turbid water, coloured in orange with soil-erosion matter where the average number of copepod species $(0.2 \pm 0.08$ species per site) was about 20 times less than in rivers with not intensively coloured by soil mater or not turbid water $(3.8 \pm 2.8$ species per site $)$. This conclusion is also supported by ANOVA analyses that indicate significant $(\mathrm{F}=25 ; \mathrm{P}=0,038)$ correlation of species number with type of river with turbid or clear water.

No any correlation was found for copepod biodiversity (number of species) plotted against river/ pond as independent variables.

Among Cyclopoid the most common species were Thermocylops cf. crassus, found in six sites, Eucyclops agiloides and Microcyclops rubellus (in five sites each); Microcylops varicans (4) and Mesocyclops aspericornis (4+1 sites in Borneo and 1 site in Kalimantan) and M. thermocyclopoides (3 sites) (Table 2). These species are known as very common copepods in Palearctic and in tropics especially in this area [Lay, Fernado, 1986; Hołyńska, 2000; Alekseev, 2002]. As an interesting rare species, large sized Macrocyclops neuter (Fig. 2G) from Kinabatangan river (St. 23) and tiny Bryocyclops cf. anninae cultivated in laboratory from leaf litter picked up in Kinabatangan virgin forest (St. 24) was found (Fig. 2A-D).

In a large pond in vicinity of the main city of Sabah, Kota Kinabalu, we found quite dense population of Mesocyclops cf. thermocyclopoides with significant proportion of trans-sexual mutation (Figs 3,4). About a third of adults in the population were presented with these female-sized but constructed as male and armed with geniculate antennule organisms.

Calanoida in our samples were presented with two species only, and Neodiaptomus botulifer (Fig. 2H,I) was found in two sites ( $2 \mathrm{~b}$ and $4 \mathrm{a}$ - both rivers). This species is also known as a common limnetic copepod widely distributed in Asia [Reddy, 1998] .

Among Harpacticoides collected from leaf litter in Kinabatangan virgin forest after exposing it in laboratory in room temperature water within several days we found a probably new for sciences species Elaphopidella sp.

Six other harpacticoid species of two familes (Phyllognathopodidae and Canthocamptidae) were also found in the Sabah samples (Table 2). We found several females Elaphoidella bidens; special features of Borneo individuals of the species are size and form of legs 5 .

Females of $E$. grandidieri were found together $E$. bidens for the first time for Borneo and did not show a clear seen differences from the other population [Gutierrez-Aguirre et al., 2011].

At first for Borneo Elaphoidella superpedalis was found in water after one week exposing of leaf litter collected in Rinabatanign virgin forest Reservation in lab. We have a not too detailed description of the species [Shen, Tai, 1964; Ishida, Kikuchi, 2000], but they very exactly match with found specimen. Only females of E. superpedalis are known. 


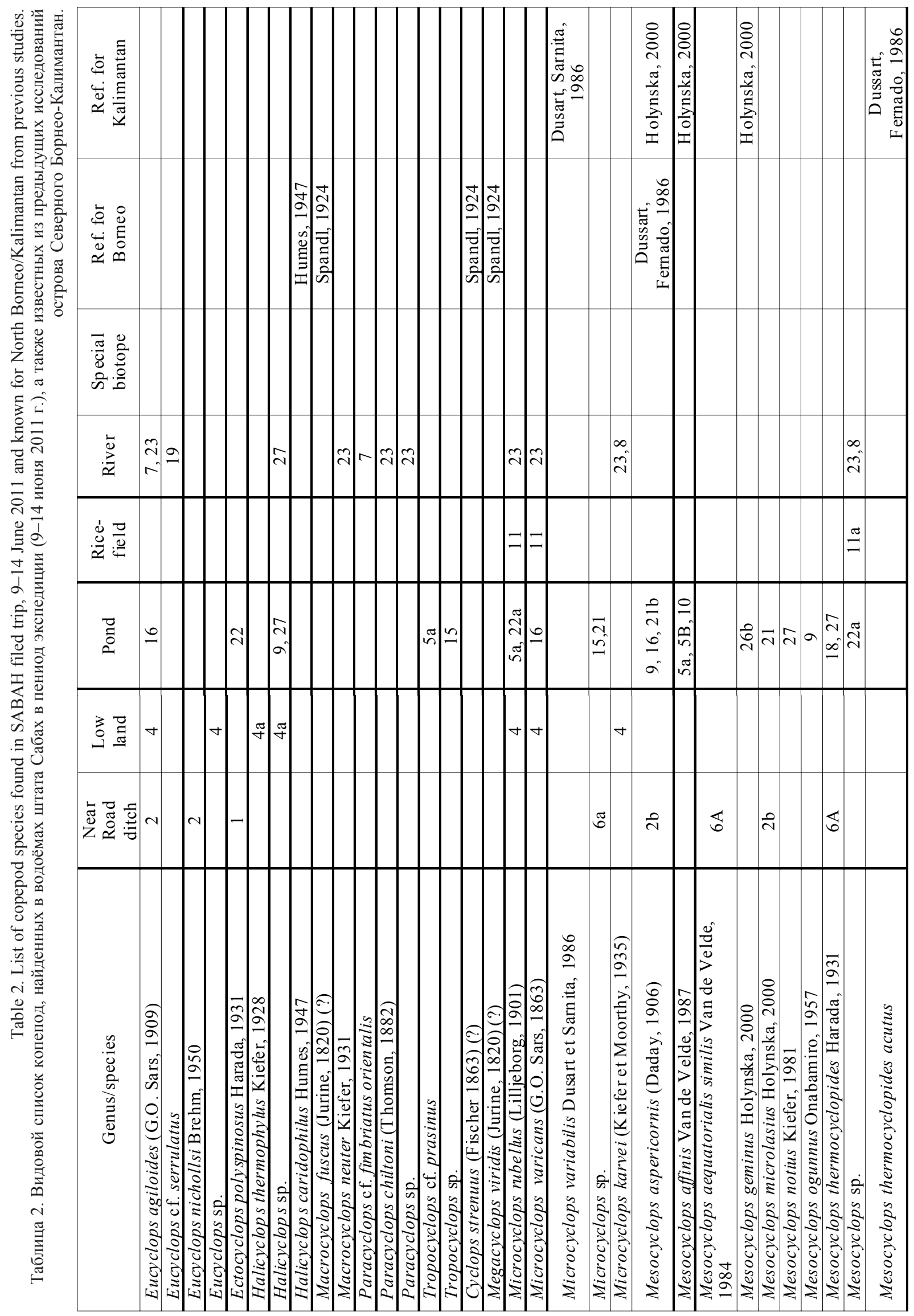




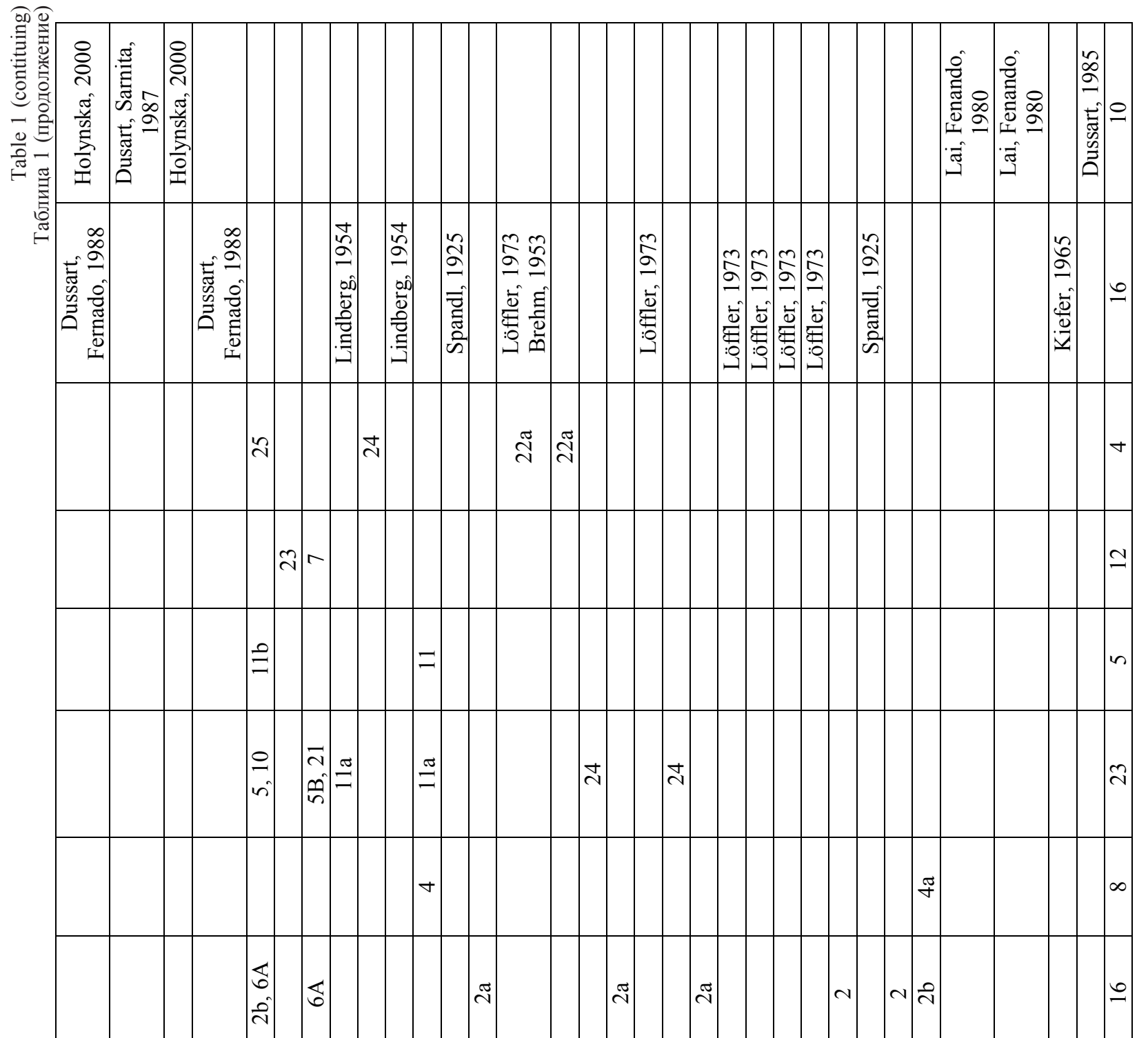

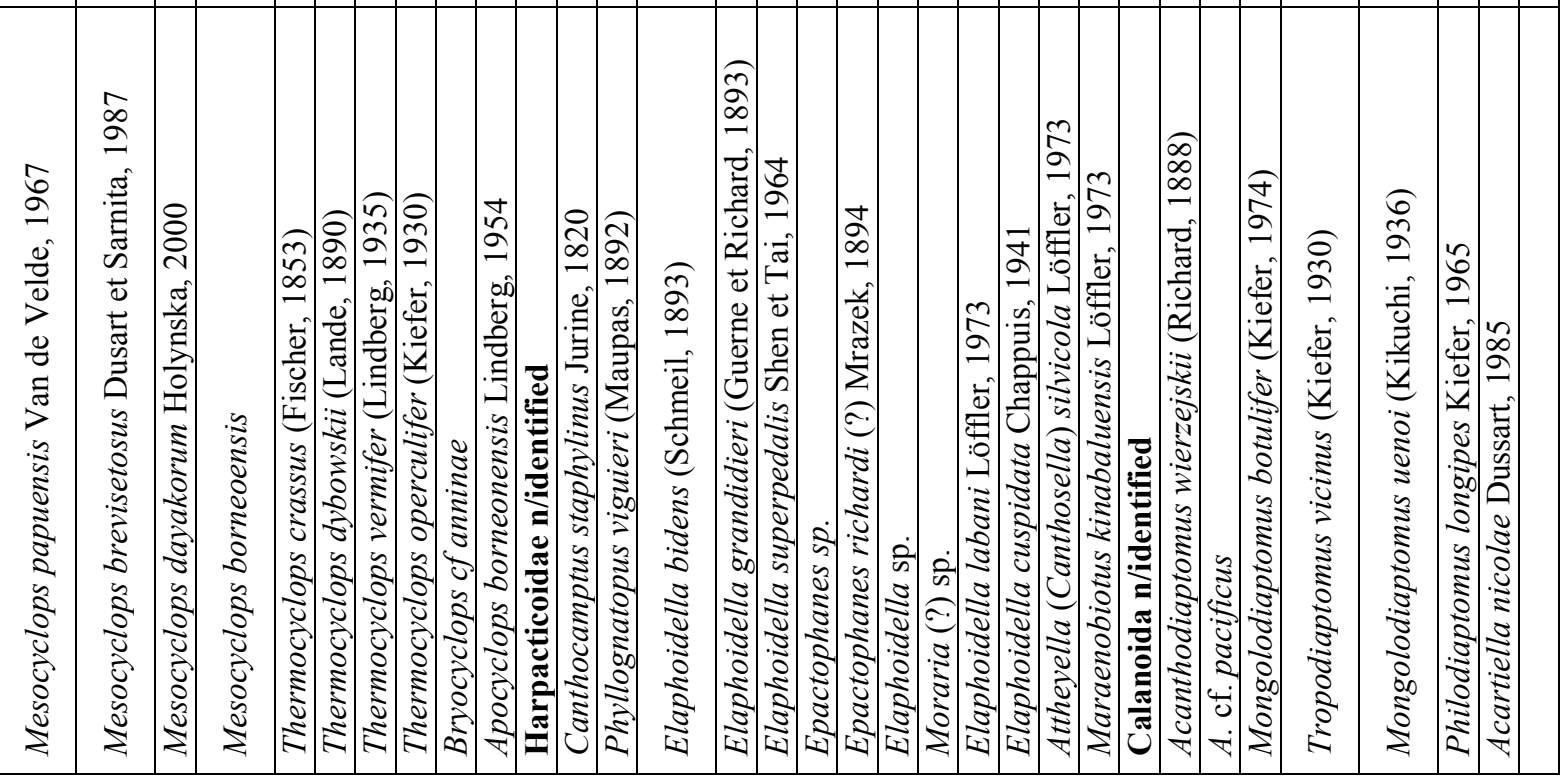


This is the second finding of genus Epactophanes in Borneo (Table 2). We found three females of the species.

Harpacticoida Phyllognatopus viguieri is wide spreaded in many SEAsian countries but at first found in Borneo.

\section{Copepod biodiversity analyses}

\section{Cyclopiformes}

The most abundant species in Borneo was found in the genus Mesocyclops, which has 13 species, reflecting the tropical origin of this genus [Rylov, 1948] with its presence in one of the mega biodiversity centers in SE Asia [Hołyńska, 2000; Alekseev, 2002; Alekseev, Sanoamuang, 2006]. On another hand, the maximum number of identified species from the genus was partly related with existence of the world revised keys for identification [Ueda, Reid, 2003].

However, the list of species found in Borneo, even now being the richest among other large islands of SE Asia, is far from completion, especially for other than Mesocyclops genera. Eucyclops is one of the promising genera that has not been revised for a long time. Eucylops includes at least five species known from SE Asia, and about the same number from other close tropical areas like India or Australia. Hereafter, a new Key for Eucyclops species possible for Borneo and surrounded territories is provided.

Key for EuCyClops SPeCies for SE Asia, Australia AND INDIA

1. Caudal rami without line of dents (serrula) on lateral margin

- Caudal rami with more or less developed serrula ......... 3

2. Caudal rami very long $\mathrm{L} / \mathrm{W}>8$; innermost caudal seta sub-equal to outermost seta

E. productus Kiefer, 1936 (Mountain India)

- Caudal rami significantly shorter, $\mathrm{L} / \mathrm{W}<5$; innermost caudal seta about 1.5 times as long as outermost seta... E. linderi Linberg, 1948 (Australia)

3. Caudal rami with reduced serrula not more than one third of external margin length

- Serrula occupies not less than half of caudal length .... 11

4. Distal setae of endopod leg 4 very long, reaching distal ends of nearest spines

- Distal setae of endopod leg 4 not so long ....................... 7

5. Distal spine of endopod leg 4 long, inner spine about 1.5 time as long as segment itself.....

E thienemanni Kiefer, 1930 (Java)

- Distal spines of endopod leg 4 shorter, inner spine about as long as segment or shorter

6. Distal spines of endopod leg 4 about as 1.5 time as short as segment

E. bryophilus Lindberg, 1950 (Mountain India)

- These spines more long inner spine about as long as segment length

.. E. ruttneri elburziensis Lindberg, 1941 (s. lat., part.) (Southern Afganistan)

7. Spine of leg 5 very short about as long as leg length; innermost caudal seta about 3 times a $\mathrm{s}$ long as outermost seta.....

.... E. neocaledonicus Dussart, 1984 (New Caledonia)
- Spine of leg 5 clearly longer than leg 5 segment; innermost caudal seta not more than 2 times as long as outermost seta of leg 5

8. Inner spine of leg 5 weak and longer than outer seta ...... E. permixtus Kiefer, 1928 (Java)

- Inner spine of leg 5 strong, knife-like and shorter than outer seta .....

9. Innermost caudal seta about twice of outermost seta, endopod leg 4 with quite long inner setae practically reaching the distal end of nearest spine

E. ruttneri Kiefer, 1933 (Java, Sumatra)

Innermost caudal seta less than 1.6 times as long as outermost seta, ENDP4 clearly non reaching the distal end of nearest spine

10

10. Caudal rami long $\mathrm{L} / \mathrm{W}=4-5$, parallel ............................

E. defectus Lindberg, 1938 (India)

- Caudal rami lshort $\mathrm{L} / \mathrm{W}=3.75$, divergent .......................... E. farsicus Lindberg, 1941 (Afganistan)

11. Spine in leg 5 reduced up to segment length, dorsal caudal seta about twice of outermost seta ...

E. nicholtsi Brehm 1953 (Tasmania, in Australia E. n. baylyi Morton, 1990 comb.n.)

- This spine clearly longer than segment, dorsal caudal seta not more than 1.3 times as long as outermost seta ... 12

12. Caudal rami long, $\mathrm{L} / \mathrm{W}=7-8$ and parallel with very small and dense.....

E. spatulatus Morton, 1990 (Australia)

- Caudal rami shorter, L/W not more than 6, usually less and more or less divergent

.. 13

13. Distal endopodial spine in leg 4 more wide in its distal end, innermost caudal seta about twice of outermost seta, the last one inserted in clear seen distance above other caudal seta ............................. E. euacanthus Sars (Pantropical, in Birma E. birmanus Lindberg, 1949)

- This endopodial spine of normal construction, innermost caudal seta less than 2 times (usually less than 1.5 times) as long as outermost seta that usually inserted more or less close to other seta

14

14. Spine in leg 5 weak and not less than 2 times shorter than outer seta .......E. semidenticulatus Lindberg, 1940 (India)

- Spine in leg 5 better developed ................................... 15

15. Antennula at 3 distal segments with serrated hyaline plate, caudal rami well divergent

E. microdenticulatus Lindberg, 1940 (India)

- Antennula at 3 distal segments with smooth hyaline plate, caudal rami low divergent or practically parallel ..... 16

16. Antennal basipodite on caudal side with two groups (position 1,2) of long hair seta .................................... 17

- Antennal basipodite on caudal side in top without long hair seta at all ............... speratus tropicalis Alekseev et Yusoff, 2013 (West Sumatra in mountains)

17. In leg4 coxal spine on both sides homogeneously with long dense hair-setae ........... E. agiloides (Sars, 1909) (Pantropical, in Australia E. australiensis Morton, 1990

- This coxal spine armed with short strong dents that on outer edge produce clear seen gap, sometime this side almost smooth ..................... E. serrulatus (Fischer 1853) (Palearctic, possible only as invasive species)

\section{Harpactiformes}

Another large set of species was presented in Borneo by Harpacticoid copepods. Early data on freshwater harpacticoid copepod species found in Borneo were 


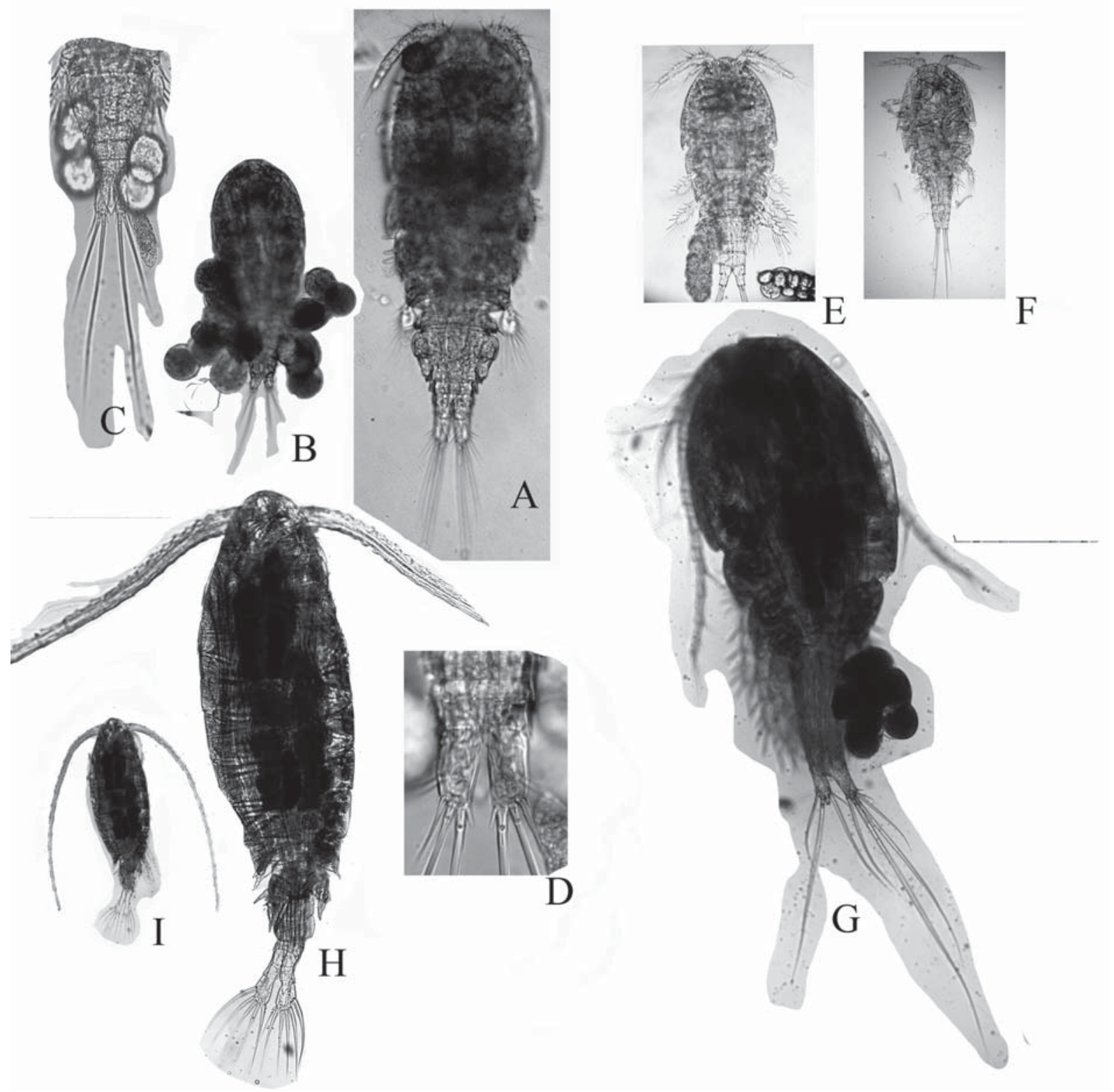

Fig. 2. Pictures of some particular copepods collected during Borneo trip. A-D - Bryocyclops cf. annae, A - eggless female, dorsally, B - female with eggs ventrally, C - female abdomen dorsally, D - female caudal rami, ventrally; E - Halicyclops thermophylus Kiefer, 1928, dorsal view; F - Halicyclops sp., ventral view; G-Macrocyclops neuter Kiefer, 1931, ventral view; H, J Mongolodiaptomus botulifer (Kiefer, 1974), dorsal view.

Рис. 2. Фотографии некоторых наиболее интересных видов копепод, собранных во время экспедиции на о. Борнео. A-D Bryocyclops cf. annae, A - самка без яиц, дорсально, В - самка с яйцами, вентрально, С - абдомен самки дорсально, D каудальные ветви самки вентрально; Е - Halicyclops thermophylus Kiefer, 1928, дорсально; F - Halicyclops sp., вентрально; G Macrocyclops neuter Kiefer, 1931, вентрально; Н, J — Mongolodiaptomus botulifer (Kiefer, 1974), дорсально.

published by Vincenz Brehm [1953] and Heinz Löffler [1973]. The first author cited only one species, Elaphoidella bidens, which was later on recognized together with four more species by the second author too [Löffler, 1973]. Three of them Maraenobiotus kinabaluensis, Elaphoidella labani and Attheyella (Canthosella) silvicola appeared to be as new for science species (see Table 2). In accordance with both previous and our data, Elaphoidella is the richest Harpacti- coid genus (presented with 6 species) in Northern Borneo, and E. bidens is the most common harpacticoid in the studied region.

Besides SE Asia, distribution of E. bidens includes also subtropical regions in Europe [Chappius, 1931; Lang, 1948; Borutsky, 1952, 1967; Apostolov, 2007]. E. bidens was previously found in ground waters of mountain area in Borneo [Löffler, 1973]. This species is known as producing several morphologically differ- 


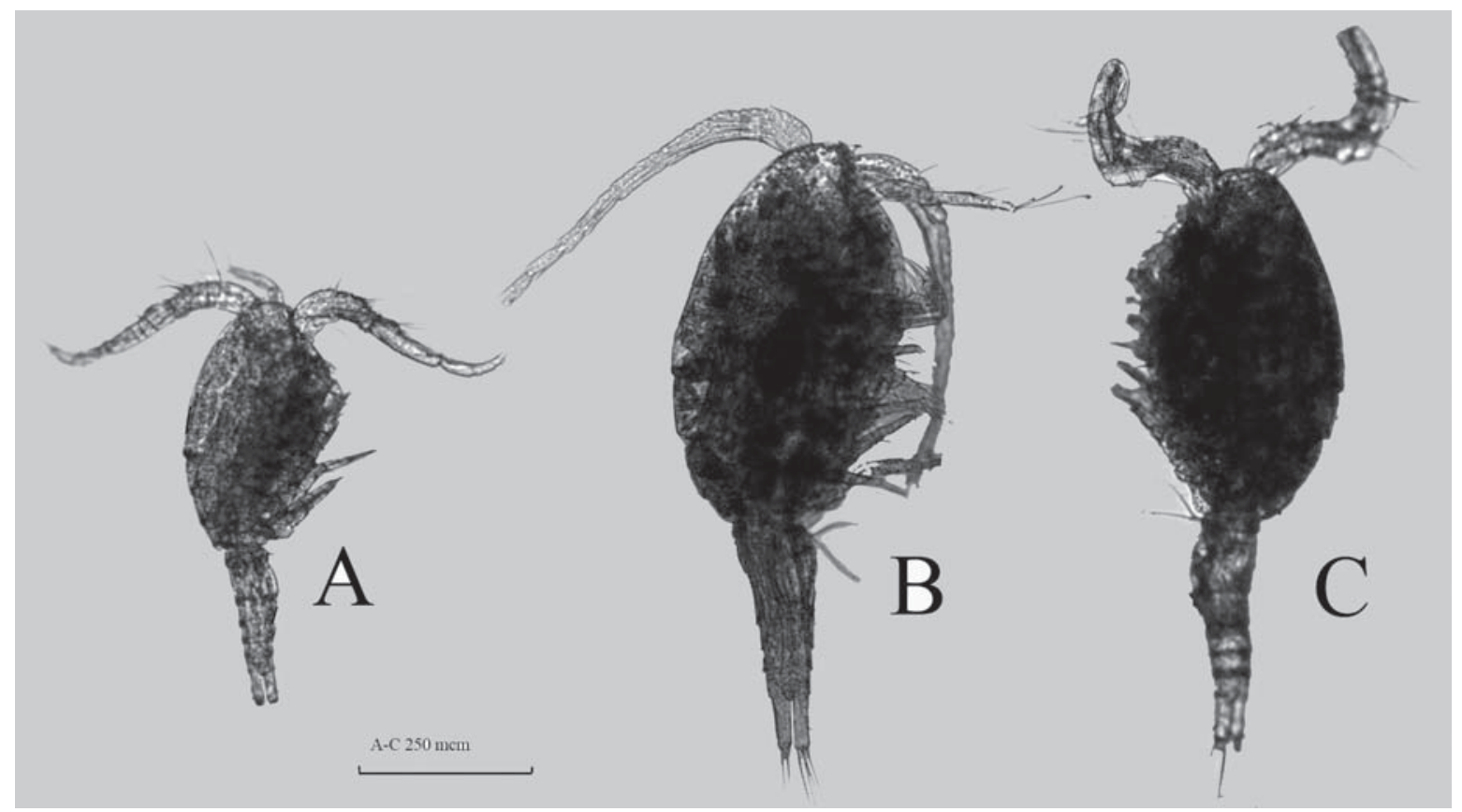

Fig. 3. Male, female and transexual individuals in population Mesocyclops thermocyclopoides Harada, 1931 site 24 , Kota Kinabalu, Borneo.

Рис. 3. Самец, самка и транссексуальный индивидуум из популяции Mesocyclops thermocyclopoides Harada, 1931, станция сбора 24, столица штата Кинабалу, Борнео.

ent forms (coronata, decorata, subtropica). Apostol Apostolov [2007] showed that the most variable elements of E. bidens like structure of body somites, endopodites of legs 1-4 (P1, P4) and caudal rami are options of high morphological variability within the species. According to this author the above-named forms have no a taxonomical value so the individuals found in Borneo can be attributed to typical E. bidens.

Females of another species of the same genus $E$. grandidieri were found together with $E$. bidens. It was the first registration of the species in Borneo and the individuals we found did not show a clear seen differences from other population. The species is also known from tropical/ subtropical areas in Africa [Chappuis, 1931; Lang, 1948], Japan [Ishida, Kikuchi, 2000], China [Borutsky, 1952], Vietnam [Borutsky, 1967], Central and Southern America [Dussart, 1982; GutierrezAguirre et al., 2011], where it inhabits lakes, wells and springs. Finding E. grandidieri in Wallacea area of SEAsia let us conclude on possible pan tropical distribution of this species.

Elaphoidella superpedalis is also specified at first for Borneo. One female was found in the leaf litter together By structure and armament of abdominal somite, caudal rami, anal operculum, and other appendages $E$. superpedalis from our sample is very close to specimens from China and Japan [Shen, Tai, 1964; Ishida, Kikuchi, 2000].As in Borneo only females of the species were recognized in China [Shen, Tai, 1964] and Japan [Ishida, Kikuchi, 2000] so this species is possibly parthenogenetic one. We found three females of Epactophanes sp. which are not identified to spe- cies level but can belong to E. philippinus or E. richardi. Because information about both species we included in Key.

To make easier identification of Harpacticoides in Borneo we produced a simple key for all species found here.

\section{KEY FOR HARPACTICOID SPECIES IN BORNEO}

1. P5 one-segmented. Apical setae on caudal rami rather short and thick

Phyllognatopus viguieri (Maupas, 1892).

- P5 two-segmented. Apical setae on caudal rami trivial ....

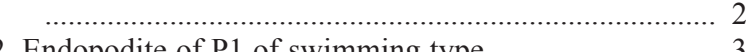

- Endopodite of P1 of prehensile type with 1 slightly bent spine, 1 long and 1 short setae ................................... 4

3. Anal operculum rounded large with 4-5 strong spines and row of thin spinules. Mandibular palp one-segmented, with 2 distal setae

... Epactophanes philippinus Bruno et Cottarelli, 1999

- Anal operculum round-shaped, small with thin spines. Mandibular palp reduced up to 1 setae Epactophanes richardi Mrazek, 1894

4. Body cylindrical. Exopodite P1 and endopodites P1-P4 two-segmented, exopodites P2-P4 three-segmented, P5 small; baseoendopodites P5 in female with 4-5 setae, baseoendopodites P5 in male with 2 setae; exopodite P5 with 3-4 setae

Maraenobiotus kinabaluensis Löffler, 1973

- Body slightly caudally narrowed, slender. Exopodites P1P4 three-segmented.

5. Endopodites P1-P4 in females two-segmented. Endopodite P4 in males one-segmented with 2 terminal setae. 


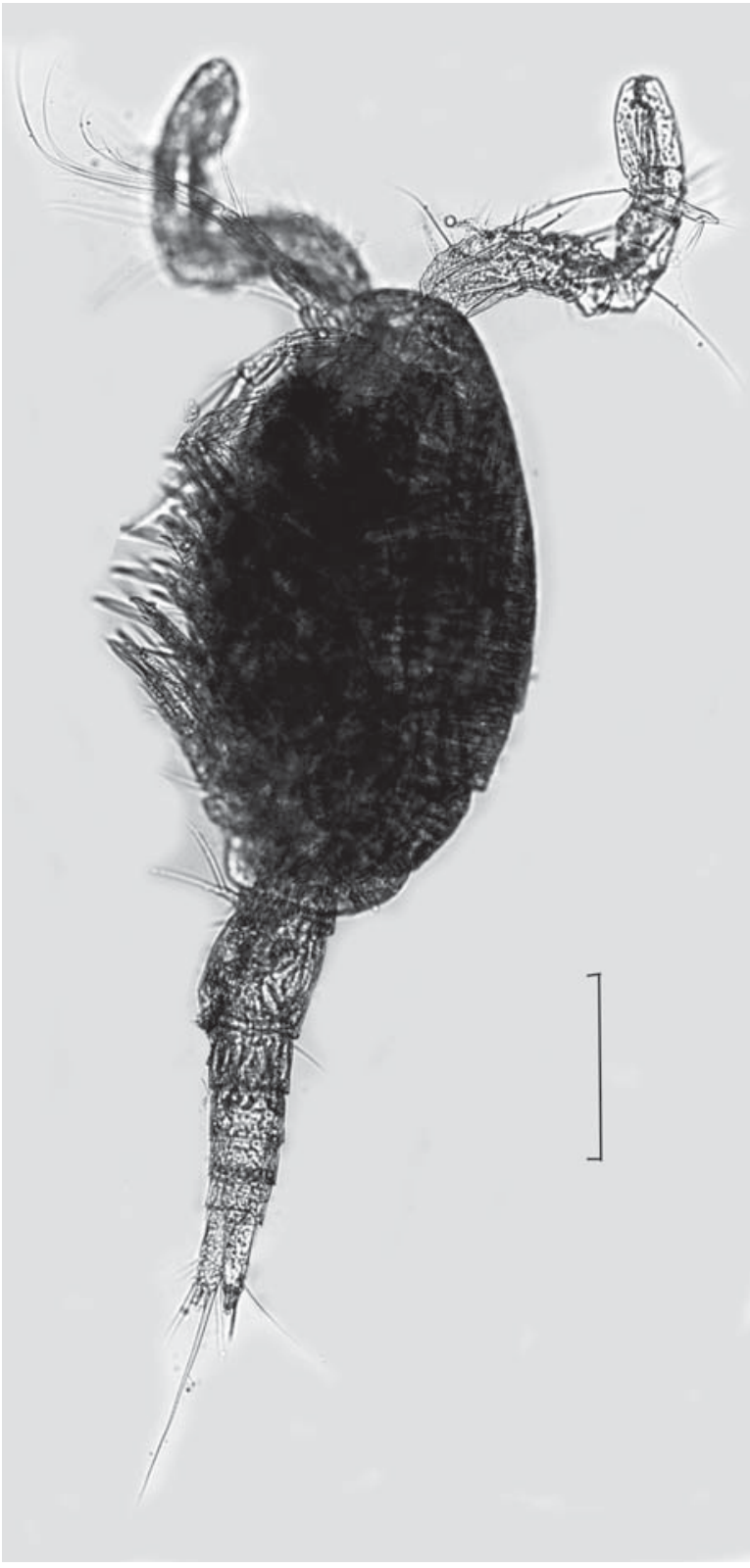

Fig. 4. Intersexual individual (female sized male) of Mesocyclops thermocyclopoides Harada, 1931.

Рис. 4. Интерсексуальный индивидуум Mesocyclops thermocyclopoides Harada, 1931 (самец по размеру равный самке).

Baseoendopodites P5 in female with 6 setae Attheyella (Canthosella) silvicola Löffler, 1973

- Endopodite P1 3-segmented, endopodites P2-P4 in female two-segmented. Baseoendopodites P5 in female with 4 setae

6. Abdominal somites on dorsal side serrated .................. 7 6

- Abdominal somites on dorsal side smooth ...................... 8

7. Caudal rami near square, with dorsal trigonal apophysis. First segment P4 without setae on inner side Elaphoidella bidens (Schmeil, 1893)

- Caudal rami in female tapering posteriorly, without apophysis on dorsal side. First segment P4 in female with setae on inner side. Male unknown Elaphoidella sp.1 (possibly local; endemic of Borneo)

8. Anal operculum small, with spines ....

- Anal operculum large with setules 9

9. Last segments endopodites P2-P3 in female about 5 times as long as wide. Exopodite P5 in female with 5 spines and setae. Apical setae on exopodite P4 in male trivial; entopodite P4 in male with 3 spines and setae Elaphoidella cuspidata Chappuis, 1941

- Last segments endopodites P2-P3 in female about 2-3 times as long as wide. Exopodite P5 in female with 4 setae. Apical setae on exopodite P4 in male in the form of cervine horns; entopodite P4 in male with 2 therminal setae ...................... Elaphoidella labani Löffler, 1973

10. Exopodite P5 in female more than 4.5 times as long as wide. Male unknown

. Elaphoidella superpedalis Shen etTai, 1964

- Exopodite P5 in female 2 times as long as wide. Male unknown ......

... Elaphoidella grandidieri (Guerne et Richard, 1893)

\section{Calaniformes}

This group of limnetic copepods in our samples from Borneo were presented only few species due to absence of large lakes in the Sabah state. The calanoids were found only in two samples, in a large rain pool near a road side (St. 2) and in the low-land area (flood plain) of Garama river (St. 4). Mongolodiaptomus botulifer (Kiefer, 1974) a wide spread diaptomid in SEAsia was also the most common calanoid species in Northern Borneo.

\section{Discussion}

The first list of species for Borneo appeared in the beginning of last century after publication of Spandl [1924] Of the three species found by him, Cyclops strenuus, Cyclops (Megacyclops) viridis, and Cyclops (Macrocyclops) fuscus, the validity of identification of the first species inhabiting mainly high latitudes in Palearctic was under doubt since the paper appeared [Lindberg, 1954]. Many references indicate that the basically Holarctic genus Cyclops tends to inhabit cold climate regions, and when found in southern countries like India, they seemed to inhabit high mountain lakes [Dussart, Dafaye, 2006]. Reference of Spandl [1924] on C. strenuus from Borneo seems like the only one for the southern (practically equatorial) site of the genus registration and until confirmation should be regarded as questionable one.

Two others species, Cyclops (Megacyclops) viridis, and Cyclops (Macrocyclops) fuscus also can be criticized for accuracy in their identification, mainly due to limitation in taxonomy during the time. First time when Spandl made his copepod identification, the dominative biodiversity paradigm among aquatic invertebrates was cosmopolitism in distribution of few very common species. In the genus, then subgenus Macrocyclops, only three valid species with practically word-wide distribution were recognized, M. albidus, M. distinctus and M. fuscus. The last two species with 
plumose inner side of caudal rami quite often were mixed and Lindberg [1954] believed that Spandl could have found $M$. distinctus in Borneo which tend to be present in hot climate zones rather than M. fuscus that is common in cold climate waterbodies. Our finding in Sabah that $M$. neuter also has hair-like seta on inner caudal surfaces, let us speculate that Spandl in the early samples from Borneo could in fact find this species that was described from SEAsia six years after his publication [Kiefer, 1931].

Megacyclops viridis is one more former cosmopolitan cyclopoid from the list of Spandl that also could be a misidentification with one the sibling species or subspecies described after publication of Spandl's paper. Among possible candidates, there are $M$. formosanus [Harada, 1931] described from Taiwan and M. latipes (Lowndes, 1927) known from Europe till Mexico and two subspecies $M$. viridis acutulus (Kiefer, 1930) from Java (the most possible variant to our mind) and $M$. viridis takebuensis Ito, 1954 from Japan.

Among Calanoida found in Borneo, Diaptomus $c f$. lamellatus identified by Brehm [1953] is also a doubtful species and possibly can be attributed to Mixodiaptomus kupelweisseri (Brehm, 1907) which was found only in southern Europe [Dussart, Defaye, 2002]. Heliodiaptomus lamellatus Sang, Shen, Li et Chen, 1975 was described several decades after Brehm's survey on copepods of Borneo [Brehm, 1953]. Epactophanes richardi Mrazek seems like the last species that also possibly was identified in Borneo incorrectly by Löffler [1973]. Until recently, only one cosmopolitan species in the genus, E. richardi Mrazek, with many variations was distinguished [Lang, 1948; Borutsky, 1952]. In Asia $E$. richardi was also known from Japan [Ishida, 1987], Vietnam [Borutsky, 1967], China [Shen et al., 1979] and from Borneo [Löffler, 1973]. In the article of Löffler [1973] there is no description nor drawing of the specimens found by him in Borneo so we could not conclude if it was E. philippinus described after Löffler's paper or not but with a high probability he identified this Epactophanes as the most morphologically close to it species $E$. richardi.

Analysis of other available literature revealed that there are 26 copepod species from the island of Borneo (Table 2). This number of species is close to copepod fauna known for Java or Sumatra [Alekseev et al., 2014]. Our one week journey in Sabah state increased the copepods for Borneo upto 60 species comprised in 20 genera (Table 2). The total copepod number for the island, including the references from Kalimantan, has been increased so far more than twice. Even after shortening the list till 48 valid names due to the presence of five doubtful species (discussed above), and seven forms identified only to genus level, the Island Borneo has now the highest copepod biodiversity known among the largest tropical islands in SEAsia.

\section{Zoogeography of copepod fauna in Borneo}

Faunistic complex of continental copepods in Borneo includes several zoogeographical elements.
Endemic species for the Borneo island were described in all suborders of Copepoda and includes: in Cyclopoida: Halicyclops caridophilus Humes, 1947, Microcyclops variabilis Dusart et Sarnita, 1986, Mesocyclops brevisetosus Dusart et Sarnita, 1987, M. dayakorum Holynska, 2000, M. geminus Holynska, 2000; in Calanoida Acartiella nicolae Dussart, 1985, Philodiaptomus longipes Kiefer, 1965 and in Harpacticoida Attheyella (Canthosella) silvicola Loeffler, 1973, Elaphoidella labani Loeffler, 1973, E. sp.1 and Maraenobiotus kinabaluensis Loeffler, 1973. This resulted in quite high level of endemism of copepod fauna in Borneo reaching $24.4 \%$ of 45 valid species names.

Another faunistic group in Borneo was created by species with pan-tropical distribution or even specified as cosmopolites. Among Cyclopoids, it includes Eucyclops agiloides (G.O. Sars, 1909), Paracyclops chiltoni (Thomson, 1882), Tropocyclops cf. prasinus, Microcyclops rubellus (Lilljeborg, 1901)], M. varicans (G.O. Sars, 1863), Mesocyclops aspericornis (Daday, 1906), and Thermocyclops crassus (Fischer, 1853). In Harpacticoides, there are Elaphoidella bidens (Schmeil, 1893) and E. grandidieri (Guerne et Richard, 1893). To our mind this group is in fact represented by flocks of sibling species that need to be revised with molecular-genetic tool using.

The third group copepods from Borneo represents Australian fauna and includes only three Cyclopoda species: Eucyclops nichollsi Brehm, 1950, Mesocyclops notius Kiefer, 1981, and M. papuensis Van de Velde, 1967. This composition indicates a transitional character of continental fauna of the island to some extent similar to that in Sulawesi.

Several Cyclopoids species more common in Africa but also known for tropical belt in Asia and in SEAsia form the fourth faunistic group: Halicyclops thermophylus Kiefer, 1928, Microcyclops karvei (Kiefer et Moorthy, 1935), Mesocyclops aequatorialis similis Van de Velde, 1984, and M. ogunnus Onabamiro, 1957.

Finally, the most abundant native group was represented by species with SEAsian, Pacific Asian and Indo-China distributions and includes about half of biodiversity in Cyclopoida (10 species), Calanoida (4 species) and Harpacticoida (4 species).

\section{Some negative trends in copepod biodiversity in Borneo}

\section{Deforestation and soil errosion}

The number of species found in different sites of Sabah was positively correlated with two environmental factors: depth and temperature. Lower copepod biodiversity in the rivers compared to the ponds could be correlated to the lower depths and temperature in the fomer than the latter. In addition, a positive correlation of copepod biodiversity with depth could be due to a more stable environment in deeper water bodies during dry season. This is probably due to the fact that deeper water bodies could provide a more favorable 
habitats for accumulation of higher number of species compared to shallow temporary biotopes.

An interesting correlation revealed from dispersal analyses indicates that the number of copepod species was negatively related to turbid water with sediments and silt and positively withclear/transparant water in rivers. In turbid water, the biodiversity was many times less than that in clear water. Apparently, deforestation in the tropics which usually resulted in soil erosion and decreased depths in rivers affect life conditions in aquatic biotopes. Results of this study revealed that changes in forest river hydrology negatively affected copepod biodiversity in Borneo rivers.

\section{Transsexual mutation}

Another human mediated negative impact on aquatic invertebrate biodiversity - intersexuality in Mesocyclops thermocyclopodes, which was discovered in a pond in Kota Kinabalu. Changing sex at the same relative body size is a quite common among different animals phenomenon known also in copepods [Allsop, West, 2003; Gusmao, McKinnon, 2009]. Intersexuality in copepods can be a back side hormone-based pesticide usage in intensive agriculture technologies. Similar intersexual changes on males in copepod Eurytemora affinis were recently found in France [Suissi et al., 2010] These effects in aquatic environment were attributed to penetration in water of a new generation of pesticides based on insecticidal hormones, like metil-farneosoate, that in our experiments transformed parthenogenetic females of a tropical crustaceans $\mathrm{Moi}$ na micrura Kurz, 1874 in males [Alekseev et al., 2012]. In Borneo aquatic ecosystems, this phenomenon could also be due to the wide usage artificial hormone-based pesticides in affected by agriculture watershed.

\section{Conclusions}

In the island of Borneo (including Kalimantan states), copepod fauna revealed the richest biodiversity among all the large islands in SEAsea (60 species comprised in 20 genera). Mesocyclops is the most abundant genus with 13 species. Continental copepod fauna in Borneo shows quite high level of endemism reaching $24.4 \%$ of 48 valid species but also includes pantropical, Australian, African and SEAsian elements. In Borneo number of species in sampling sites was positively related with temperature and depth that possibly related with dominative sites (rivers and ponds). The highest copepod biodiversity in Borneo were found in ponds (23 species), near road ditches (15), rivers with transparent water (12), and low-land or swamp areas related with rivers (9). The lowest number of species were found in rivers with turbid water coloured in orange with soil-erosive matter that probably indicate a negative effect of human mediated deforestation process on aquatic biodiversity in Borneo. In addition, discovering intersexual modification in some urbanite populations of copepods in Borneo could be an alarm- ing signal on the negative effects of hormone-based pesticide on aquatic ecosystems. Within practically each copepod genus studied in Borneo there are forms with problems on species identification by existing faunistic keys. This possibly indicates a necessity of new species description from this area in the nearest future.

ACKNOWLEDGEMENTS. We are thankful to Mr. Perumal Kuppan (UPM Science officer), student, Mr. Azuraidi, and our driver Mr Anding for their assistance with field work. Dr. Hans Mittmann (Karlsruhe Natural History Museum, Germany) kindly helped to work with VA on Prof. F. Kiefer's reference collection. We would like to thank Dr. Maria $\mathrm{Ho}^{3}$ yñska (Museum and Institute of Zoology of the Polish Academy of Sciences), Dr. Walter T. Chad (Smithsonian Institution Museum Support Center) and Dr. Janet W. Reid (Virginia Museum of Natural History) for their kind help with literature on harpacticoid fauna. This study was made possible through funding from the grant RFBR \# 1404-00195-a and a visiting professor fellowship for VA from Universiti Putra Malaysia

\section{References}

Alekseev V. 2002. Copepoda // C.H. Fernando (ed.). A guide to tropical freshwater zooplankton. Identification, ecology and impact on fisheries. Backhuys Publishers. P.123-187.

Alekseev V., Sanoamuang L. 2006. Biodiversity of cyclopoid copepods in Thailand - with a description of Afrocyclops henrii sp. n./ / Arthropoda Selecta . Vol.15. P.277-290.

Alekseev V., Raha A.R., Shamsudin M.N., Yusoff F.M. 2012. Effects of chemical sexual signals on life cycle parameters in tropical cladoceran Moina micrura Kurz, 1874 mimicked by using insect juvenile hormone methyl farneosoate // Proc. Int. Sci. Conf. Modern Directions of Theoretical and Applied Researches. Vol.32. P.18-26.

Alekseev V, Haffner G.D., Vaillant J.J., Yusoff F.M. 2013. Calanoid and cyclopoid copepod biodiversity in Indonesia with emphasis on Sulawesi Island // Journal of Limnology. Vol.72. No.2. P.243-274.

Allsop D.J., West S.A. 2003. Changing sex at the same relative body size // Nature. Vol.425. P.783-784.

Apostolov A. 2007. Notes sur les harpacticoides cavernicoles (Crustacea: Copepoda) de Vietnam du nord // Historia Naturalis Bulgarica. Vol.18. P.65-73.

Borutsky E.V. 1952. [Crustacea. Freshwater Harpacticoida] // Fauna SSSR. Rakoobraznye. Vol.3. No.4. Moscow-Leningrad: AN SSSR Publ. 426 p. [in Russian].

Borutsky E.V. 1967. [Freshwater Copepoda Harpacticoida of the North Vietnam] // Zoologicheskiy Zhurnal. Vol.46. P.10151022 [in Russian].

Brehm V. 1953. Notes about freshwater microfauna of Borneo and Cebu (Philippines) // Meeting Messages of Austrian Academy of the Sciences of Mathematical-scientific Class. Vol.1. P.163169.

Bruno M.C., Cottarelli V. 1999. Harpacticoids from groundwaters in the Philippines: Parastenocaris mangyans, new species, Epactophanes philippinus, new species, and redescription of Phyllognathopus bassoti (Copepoda) // Journal of Crustacean Biology. Vol.19. P.510-529.

Chappuis P.A. 1931. Copepoda Harpacticoida der Deutschen Limnologischen Sunda-Expedition // Archiv für Hydrobiologie, Supplementband 8, Tropische Binnengewässer. Bd.1. S.512584.

De Man J.G. 1898. Zoological results of the Dutch scientific expedition to Borneo // The Crustaceans Notes of the Leyden Museum. Vol.20. P.137-161. 
Dussart B.H. 1982. Copepods of Islands Antilles // Heu. Hydrobiol. Trop. Vol.16. P.313-324.

Dussart B.H. 1985. Sur quelques Copepodes d'Amerique du Sud 5. Diaptomidae // Archiv für Hydrobiolgie. Vol.103. P.201215 .

Dussart B.H., Defaye D. 2002. [World directory of the Crustacea Copepoda of inland waters. Vol. I. Calaniformes]. Leiden: Backhuys. 285 p.

Dussart B.H., Defaye D. 2006. [World directory of the Crustacea Copepoda of inland waters. Vol. 2. Cyclopiformes]. Leiden: Backhuys. 354 p.

Dussart B.H., Fernando C.H. 1986. The Mesocyclops problem today // Syllogeus. Vol.58. P.288-293.

Dussart B.H., Fernando C.H. 1988. Sur quelque Mesocyclops (Crustacea, Copepoda) // Hydrobiologia. Vol.127. P.241-264.

Dussart B.H., Sarnita A.S. 1987. A new freshwater copepod, Mesocyclops brevisetosus sp.nov.(Crustacea, Copeoda) from Kalimantan, Indonesia // Canadian Journal of Zoology. Vol.65. P. 2731-2733.

Galassi D.M.P., De Laurentiis P., Fiasca B. 2011. Systematics of the Phyllognathopodidae (Copepoda, Harpacticoida): re-examination of Phyllognathopus viguieri (Maupas, 1892) and Parbatocamptus jochenmartensi Dumont and Maas, 1988, proposal of a new genus for Phyllognathopus bassoti Rouch, 1972, and description of a new species of Phyllognathopus // ZooKeys. Vol.104. P.1-65.

Gusmao L.F.M., McKinnon A.D. 2009. Sex ratios, intersexuality and sex change in copepods // Journal of Plankton Researches. Vol.31. P.1101-1117.

Gutierrez-Aguirre M.A., Suarez-Morales E., Cervantes-Martinez A., Sarma N., Sarma S.S.S. 2011. Morphology of Elaphoidella grandidieri (Guerne \& Richard, 1893) (Copepoda, Harpacticoida) from Mexico with notes of fecundity in culture conditions // Studies on Freshwater Copepoda: A Crustaceana Volume in Honour of Bernard Dussart. Leiden: Brill Publishers. P.227-244.

Holyńska M. 2000. Revision of the Australasian species in the genus Mesocyclops (Copepoda, Cyclopoidae) // Annales Zoologici (Warszava). Vol.50. P.363-447.

Huys R., Boxshall G. 1991. [Copepod evolution]. London: The Rayaial Society. 468 p.

Humes A.G. 1947. A new cyclopoid copepod // Microscopic Society Menasha. Vol.66. No.3. P.293-301.

Ishida T. 1987. Freshwater Harpacticoid Copepods of Hokkaido, Northern Japan // Scientific Reports Hokkaido Salmon Hatchery. Vol.41. P.77-119.

Ishida T. 2002. [Illustrated fauna of the freshwater Cyclopoid Copepods of Japan] // The Bulletin of the Biogegographical Society of Japan. Vol.57. P.37-106 [in Japanese].

Ishida T., Kikuchi Y. 2000. Illustrated fauna of the freshwater Harpacticoid copepods of Japan // Bulletin Biogegographical Society of Japan. Vol.55. P.7-94.

Kiefer F. 1931. Kurze Diagnosen neuer Susswassercopepoden // Zoologischer Anzeiger. Bd.94. S.219-224.
Kiefer F. 1965. Beitrage zur Copepodenkunde. Eine neue Art der Gattung Phyllodiaptomus // Zoologischer Anzeiger. Bd.175. S. $460-465$.

Lai H.C. 1986. The freshwater Calanoida (Crustacea, Copepoda) of Indonesia // Indo-Malayan Zoology. Vol.3. P.39-61.

Lai H.C., Fernado C.H. 1980. Zoogeographical distribution of SouthEast Asian freshwater Calanoida // Hydrobiologia. Vol.74. P.53-66.

Lang K. 1948. Monographie der Harpacticoiden. Lund: Håkan Ohlsson. Bd. 1, 2. $1683 \mathrm{~S}$.

Lindberg K. 1954. Cyclopides (Crustacés Copépodes) d'îles du Pacifique Sud (Mélanésie et Micronésie) et de Bornéo // Kunglige Fysiografiska Sällskapets i Lund Förhandlingar. Vol.24. P.1-14.

Löffler H. 1973. Die Harpacticidenfauna des Mt. Kinabalu (Borneo) mit besonderer Berücksichtigung der Gattung Maraenobiotus nebst Angaben zur Harparticidenfauna des Gebietes Nuwara (Hochplateau Ceylon) // Hochgebirgsforschung. Bd.3. S.5-28.

Reddy Y.R. 1994. [Copepoda: Calanoida: Diaptomidae] // H. Dumont (ed). Guides to the identification of the microinvertebrates of the continental waters of the world. No.5. Stuttgart, Jena, Lübek, Ulm: Gustav Fischer Publishers. 221 p.

Rylov V.M. 1948. [Freshwater Cyclopoida] // Fauna SSSR. Rakoobraznyje. Vol.3. No.3. Leningrad: AN SSSR Publ. 318 p. [in Russian].

Shen C.J., Tai A.Y. 1964. [Descriptions of new species of freshwater Copepoda from Kwangtung Province, South China] // Acta Zootaxonomica Sinica. Vol.1. P.367-396 [in Chinese, with English summary].

Shen C.J., Tai A.Y., Song Y.Z. 1979. Fauna Sinica. Crustacea. Freshwater Copepoda. Harpacticoida // Science Press. Peking, China. P.164-300.

Simone L.R.L. 2006. Land and freshwater molluscs of Brazil. São Paulo, Brazil: EGB, Fapesp. 390 p.

Spandl H. 1924. Entomostraken von Borneo // Annalen des Naturhistorischen Museums in Wien. Bd.38. S.89-95.

Souissi A., Souissi S., Devreker D., Hwang J.S. 2010. Occurrence of intersexuality in a laboratory culture of the copepod Eurytemora affinis from the Seine estuary (France) // Marine Biology. Vol.157. P.851-861.

Tsalolikhin S., Yusoff F.M., Alekseev V. 2012. To the fauna of free-living freshwater nematodes (Nematoda) of North Borneo // Zoosystematica Rossica. Vol.21. P.10-17.

Ueda H., Reid J.W. 2003. Copepoda: Cyclopoida. Genera Mesocyclops and Thermocyclops // Guides to the identification of the microinvertebrates of the continental waters of the world. Leiden: Backhuys. No.5. 221 p.

WWF-Cannon. 2010. Heart of Borneo: My home, my island, my future // British High Commission Brunei Darussalam, CfBT, WWF, and International School Brunei accessed on 1 August 2010 at http://heartofborneo.cfbt.org/bn/Heartofborneo/images/hobpamsec.pdf

Responsible editor K.G. Mikhailov 